\title{
Prévention et détection précoce du cancer gastrique
}

\author{
R. LAMBERT \\ Hôpital Edouard-Herriot - Lyon (France)
}

\section{Prevention and early detection of gastric cancer}

\section{LES BASES}

D'importants travaux ont été consacrés à l'épidémiologie des cancers de l'estomac, à l'examen histologique de la muqueuse gastrique de ces patients, à la mesure de l'activité fonctionnelle des cellules pariétales, aux stades de la cancérogénèse expérimentale. On trouvera dans leur analyse [9] les bases rationnelles d'une politique de prévention et de détection du cancer de l'estomac.

1) L'environnement joue un rôle essentiel dans le développement du cancer gastrique [1]. Il s'agit du régime alimentaire; certains composés sont réputés inducteurs (aliments salés, aliments fumés, tabac, aflatoxine, nitrosamines directement ou par l'intermédiaire de la transformation nitrates-nitrites...), d'autres sont réputés protecteurs (lait, légumes verts, fruits riches en vitamine $\mathrm{C}$ ). Les facteurs exogènes liés au régime alimentaire interviennent dans les premières années de la vie en induisant la prédisposition. Ultérieurement, tout au long de l'existence, l'effet de sommation de facteurs protecteurs et inducteurs, conditionne le développement de l'état précancéreux et le passage au cancer confirmé. Ces notions expliquent le très long intervalle séparant le déclenchement de la prédisposition de celui du cancer. Lorsque l'on compare le Japon (pays à risque élevé de cancer) et les Etats-Unis (pays à risque faible) on comprend qu'un japonais transplanté aux Etats-Unis immédiatement après sa première enfance, conserve un risque de cancer gastrique plus élevé que celui de son contemporain amé-

Tirés à part: R. LAMBERT, INSERM U 45, Laboratoire de Physiopathologic Digestive, PavilIon H, Hôpital E. Herriot, 69374 Paris Cedex 2 (France). ricain, mais plus faible que celui du japonais non transplanté.

2) La gastrite chronique, lésion précancéreuse, représente le seul précurseur important du cancer gastrique. Ce rôle est démontré par les corrélations épidémiologiques entre les deux affections et la génèse des cancers gastriques expérimentaux. Le plus souvent la gastrite chronique est accompagnée de métaplasie intestinale, d'où la corrélation particulièrement significative entre métaplasie intestinale et cancer gastrique.

3) La gastrite chronique, atteinte inflammatoire évolutive de la muqueuse gastrique, associe l'atrophie des cellules à renouvellement lent (les glandes gastriques) à la dysplasie des cellules à renouvellement rapide (l'épithélium de revêtement et des cryptes). La dysplasie épithéliale se caractérise par des stades croissants d'atypie cellulaire et de dédifférentiation avec perte du caractère mucosécréteur, réduction de la durée de vie des cellules et augmentation de la fréquence des mitoses. Très souvent (70\% des cas environ), la dysplasie est accompagnée de métaplasie intestinale avec apparition d'entérocytes plus ou moins différenciés et de cellules caliciformes. Le cancer nâ̂t dans la couche profonde de l'épithélium, au niveau même de la zone de renouvellement cellulaire. Lorsque la dysplasie est simple il revêt le type indifférencié ; lorsqu'elle est accompagnée de métaplasie intestinale il revêt le type différencié intestinal. Si le foyer métaplastique intestinal est très souvent associé au cancer, il n'est pas démontré qu'il en soit le point de départ direct.

Mots clés : cancer de l'estomac, état précancéreux, prévention.

Key-words: gastric cancer, precancerous states, prevention. 


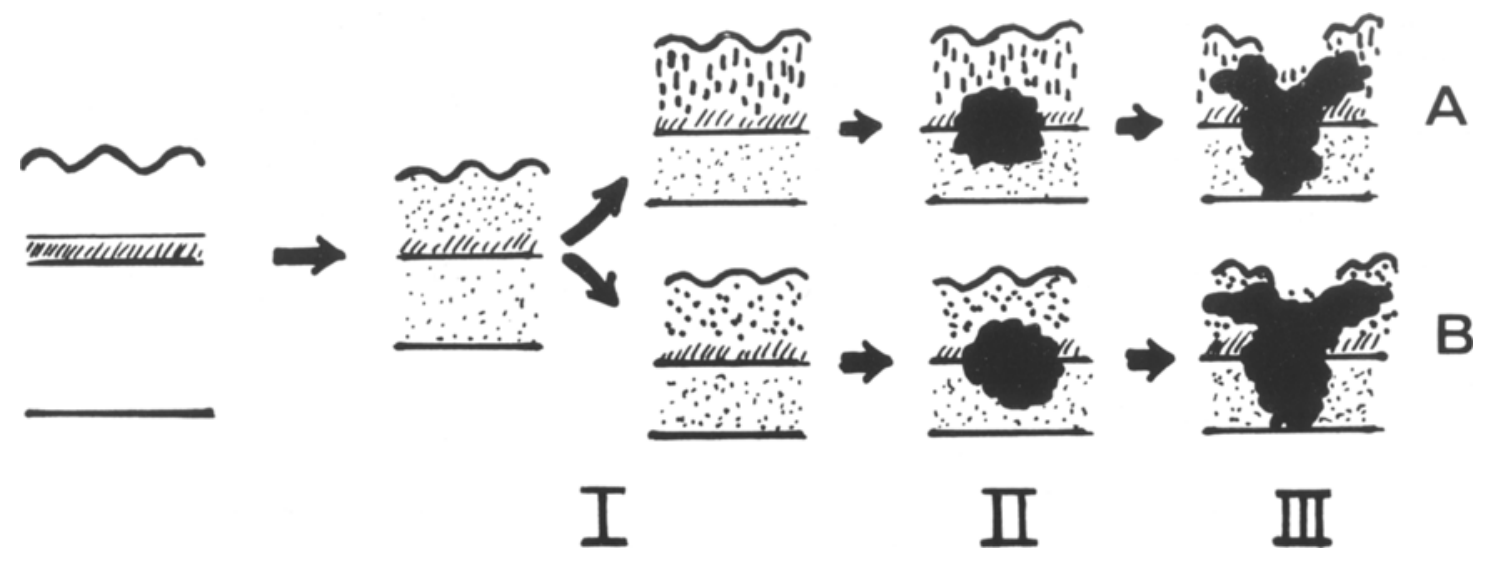

Figure 1

De la dysplasie épithéliale au cancer gastrique

La muqueuse gastrique normale (à gauche de la figura) est schématisée avec une étroite zone de renouvellement entre l'épithélium de surface (en haut) et les glandes (en bas).

Au stade I, la gastrite est caractérisée par deux phénonènes: - l'atrophie de la couche des glandes (cellules à renouvellement lent), - la dysplasie de l'épithélium de surface (cellules à renouvellement rapide). La dysplasie épithéliale se traduit par une dédifférenciation cellulaire banale avec augmentation des mitoses (type A) ou par une métaplasie intestinale (type B). Dans les deux cas elle réalise un foyer épithélial avec des degrés croissants d'atypie cellulaire (stades de Nagayo [4]).

Au stade II, le cancer (stade $V$ de la dysplasie) naît dans la zone de renouvellement cellulaire. II prend le type indifférencié avec cellules en chaton de bague si la dysplasie est de type $A$; le type différencié avec cellules de type intestinal si la dysplasie est de type B avec métaplasie intestinale. Il s'agit d'un cancer microscopique de l'estomac [5].

Au stade III, le cancer s'étend en demeurant intra muqueux et s'accompagne souvent d'ulcération en surface. C'est un cancer superficiel de l'estomac dont l'ulcération peut évoluer selon le cycle des ulcères malins décrit par Sakita [10].

En effet le tissu métaplasique n'a pas les caractères cinétiques [12] ou biochimiques [13] que l'on attribue en général à la muqueuse gastrique précancéreuse. Cependant il peut intervenir indirectement dans la transformation maligne : ainsi il a été suggéré à titre d'hypothèse que le tissu intestinal métaplasique absorbait les cancérogènes digestifs qui se trouvaient bloqués dans le chorion sous jacent.

En fait les stades precessifs du cancer gastrique sont comparables à ceux qui ont été décrits pour le cancer du colon (dysplasie du polype adénomateux) ou le cancer du col utérin (dysplasie sur métaplasie épidermoide). Au niveau de l'estomac le classement est le suivant: i) dysplasie épithéliale avec ses stades progressifs, ii) cancer microscopique d'un diamètre inférieur à $5 \mathrm{~mm}$, iii) cancer intramuqueux pur ou pénétrant la sous muqueuse, plus étendu, iv) cancer invasif pénétrant la paroi de plus en plus profondément (2).
4) Les indicateurs de l'état précancéreux gastrique peuvent-il être recherchés dans l'analyse de la sécrétion gastrique? En fait la mesure du débit acide reflète l'atrophie des glandes fundiques mais non celle des glandes antrales. Le dosage des isoenzymes de la lactodeshydrogenase dans le suc gastrique avec élévation du rapport des sous-unités $\mathrm{M} / \mathrm{H}$ n'a pas encore de portée pratique. Aussi la primauté revient, elle, toujours aux critères histologiques recueillis par la biopsie dirigée. Le premier indicateur est l'atrophie des glandes antrales ou fundiques attirant l'attention sur la dysplasie épithéliale associée. Bien que la gastrite chronique atrophique soit un processus diffus, la recherche de l'état précancéreux est axée sur l'étude de foyers dysplasiques limités dont la surface légèrement surélevée ou déprimée ne dépasse pas un à quelques centimètres carrés. Ces foyers épithéliaux atypiques $(4,6,7,11)$ prédominent sur la muqueuse antrale, sont en général multiples et peuvent être associés à 
une lésion localisée de l'estomac: ulcère ou cancer. Le cancer gastrique peut donc avoir une origine pluricentrique. La biopsie au niveau de ces îlots montre soit une métaplasie intestinale (type élevé ou déprimé), soit une dysplasie simple.

L'examen du prélèvement permet de classer le foyer épithélial atypique en degrés croissants d'atypie cellulaire selon des caractères cytologiques : forme du noyau, rapport nucleo-cytoplasmique, architecture générale des lames cellulaires. On distingue avec Nagayo [4] le stade I : muqueuse normale, les stades II et 11I: dysplasie de plus en plus marquée, le stade IV: dysplasie très sévère, le stade $V$ : cancer certain.

5) Le cancer gastrique macroscopique, au stade suivant, s'étend sur une surface plus importante tout en demeurant limité à la muqueuse et/ou la sous muqueuse. En général le cancer à ce stade se présente comme un foyer dysplasique étendu, superficiellement ulcéré. L'ulcération peut cicatriser et récidiver selon le cycle évolutif et l'ulcère malin [10]. Moins souvent, il s'agit d'un ulcère profond dont le cratère est creusé en tissu non tumoral; plus rarement encore d'un polype adénomateux dégénéré.

\section{LA PREVENTION}

Une prévention efficace du cancer gastrique implique la connaissance précise des facteurs cancérogènes et leur exclusion du régime alimentaire pour toute la population, dès la première enfance. Bien qu'il n'y ait aucune politique de santé dans ce domaine, cette prévention est réalisée de façon spontanée, en France comme dans la plupart des pays occidentaux à civilisation industrielle. En effet l'incidence du cancer de l'estomac ne cesse de décroître dans les dernières décades, avec un rythme rapide : $30,2 \%$ entre 1952 et 1968 [1]. Bien que cette prévention «inconsciente " soit efficace il est souhaitable de développer les contrôles alimentaires et l'analyse des facteurs cancérogènes dans le régime, pour en définir les bases rationnelles.

\section{LA DÉTECTION}

La détection doit être opérée à un stade précoce pour permettre une thérapeutique efficace : dysplasie au stade IV de l'état précancéreux, cancer confirmé au stade microscopique ou superficiel, muqueux ou sous muqueux. La détection de masse chez les sujets asymptomatiques appliquée pratiquement au Japon n'a pas d'intérêt dans notre pays, où le risque de cancer gastrique est nettement plus faible (taux de mortalité inférieur à 20/100000). Il faut donc se limiter à la détection chez des sujets consultant un médecin pour des symptômes digestifs. Les méthodes de détection et de surveillance seront appliquées à ceux qui ont un risque anormalement élevé :

Les sujets à risque élevé : ce sont les patients porteurs d'une maladie gastrique localisée, accompagnée de gastrite atrophique chronique. i) l'ulcère gastrique (ulcère bénin) implique un risque plus élevé de cancer, même en faisant abstraction de l'erreur possible avec un cancer ulcéré (ulcère malin). Ce risque est lié aux foyers de dysplasie épithéliale, soit sur la berge de l'ulcère, soit à distance. L'examen minutieux de pièces opératoires a pu en effet montrer de petits cancers (cancer microscopique) à distance d'un ulcère bénin [5]. ii) l'ulcère duodénal n'implique pas un risque accru de cancer au niveau de la muqueuse fundique mais au niveau de la muqueuse antrale. Les lésions de gastrite antrale ont un potentiel malin lorsqu'elles sont sévères, avec dysplasie de type IV et métaplasie intestinale, expliquant le développement paradoxal d'un cancer gastrique chez un patient hyper ou normochlorhydrique. iii) le cancer gastrique lui-même implique un risque accru de cancer en un autre point de l'estomac car les foyers dysplasiques sont volontiers multicentriques. Le dépistage de ces foyers avant l'opération permettra de mieux choisir l'étendue de la résection et de réduire le risque de récidive sur la muqueuse gastrique laissée en place. iv) le polype adénomateux est susceptible de dégénérescence maligne mais le risque n'est pas supprimé par la polypectomie car le cancer peut se développer à distance sur les foyers dysplasiques. Si les polypes hyperplasiques non adénomateux ne dégénèrent pas, ils impliquent le même risque de cancer à distance de la lésion car ils surviennent sur une muqueuse de gastrite atrophique. v) enfin tout sujet por- 
teur d'une résection gastrique étendue a un risque plus élevé de cancer car le reflux intestinal favorise le développement des lésions dysplasiques épithéliales dans l'estomac restant.

Chez les sujets se plaignant de troubles dyspeptiques banaux sans maladie gastrique localisée; une atrophie gastrique confirmée par l'histologie et l'hypochlorhydrie implique un risque de cancer d'autant plus élevé que le jeune âge du sujet ( 40 à 50 ans) permet d'escompter un effet cumulatif, en fonction du temps. L'association d'une achlorhydrie complète et d'une anémie pernicieuse signe un risque considérable dont la portée pratique est souvent minimisée par l'âge avancé du patient au moment de la détection.

Méthode de surveillance: la radiographie, à condition qu'elle soit faite en double contraste, est susceptible de détecter les lésions superficielles de la muqueuse gastrique : elle ne peut cependant se comparer à l'endoscopie puisqu'elle ne permet pas l'examen histologique des foyers dysplasiques. Aujourd'hui la surveillance des sujets à risque élevé, repose sur la seule endoscopie. Celle-ci doit répondre impérativement aux critères d'un examen de surveillance à répéter à intervalle de 12 à 24 mois. Il faut être efficace tout en ne rebutant pas le patient. L'orientation méthodologique est la suivante: a) examens par appareils de faible calibre, mais il est nécessaire d'améliorer encore la qualité des biopsies; b) recours aux techniques de coloration (bleu de méthylène) pour repérer les foyers épithéliaux atypiques en accentuant les contrastes de relief et en jouant sur les différences de coloration de la muqueuse nor- male (non colorée), de la muqueuse intestinale tement coloré) ; c) analyse fine en variant la mise au point de l'architecture épithéliale dysplasique [3] ; d) codification des lésions dysplasiques en degrés croissants d'atypic cellulaire; e) rigueur de l'iconographie pour conserver un témoin objectif de l'aspect de la muqueuse à une date donnée.

\section{CONCLUSIONS}

Une politique de détection précoce du cancer de l'estomac est régulièrement suivie d'un progrès dans le pourcentage des cancers détectés au stade muqueux ou sous-muqueux et chirurgicalement curables. Ces cancers superficiels sont dépistés par les biopsies pratiquées systématiquement devant tout ulcère gastrique et toute lésion plane étendue (cancers type II a, $b, c)$. L'indication de résection gastrique ne prête guère à la discussion sauf lorsque l'âge du patient ou l'association de tares viscérales suggèrent un risque opératoire disproportionné.

Les conséquences pratiques de la politique de détection précoce sont plus difficiles à définir lorsqu'il s'agit d'un état précancéreux ; foyers dysplasiques au stade IV. Faut-il proposer d'emblée une solution radicale, c'est-à-dire la résection gastrique, ce qui pourrait élargir à l'excès le nombre des indications opératoires ? Faut-il resserrer le rythme de la surveillance? Faudra-t-il faire une place à une microchirurgie endoscopique avec le laser? La réponse devra attendre quelques années.

\section{REFERENCES}

1. AUDIGIER J.C. et LAMBERT R. - Epidémiologie des cancers du tube digestif. Arch. Franc. Mal. App. Diges., 1974, 63, 413-432.

2. LAMBERT R. - Les bases rationnelles du prorostic du cancer gastrique opéré. Arch. Franç. Mal. App. Diges., 1975, 64, 679-696.

3. MIKAYE T. and SUZAKI. - Dissecting microscope studies an atypical epithelial focus of the gastric mucosa. Gastroenterol., Japon, 1971, $6,168-170$.
4. NAGAYO T. - Histological diagnosis of biopsied gastric mucosae with special references to that of bordeline lesions. Gann 11, Monograph., 1971, 11, 245-256.

5. NAGAYO T. - Microscopical cancer of the stomach. A study on histogenesis of gastric carcinoma. Int. J. cancer, $1975,16,52-60$.

6. NAGAYO T., YOKOYA M.A.H. and KOMAGOE T. - Early phases of human gastric cancer. Morphological study. Gann, 1965, 56, 101-120. 
7. NAKAMURA K., SUGANO H.. TAKAGI K. and FUCHIGAMI A. - Histopathological study on early carcinoma of the stomach: criteria for diagnosis of atypical epithelium. Gann, 1966, 57, 613-620.

8. NAKAMURA K., SUGANO $\mathrm{H}$. and TAKAGI $\mathrm{K}$. - Carcinoma of the stomach in incipient phases: its histogenesis and histological appearences. Gann, 1968, 59, 251-258.

9. POTET F. - Early gastric carcinoma. Cancer gastrique au début? cancer superficiel de l'estomac. Gastroenterol. Clin. Biol., 1977, I, 313318.

10. SAKITA T., TOGURO Y., TAKASU S., FUKUTOMI H., MIWA K. and YOSHIMORI M. - Observations on the healing of ulcerations in early gastric cancer. The cell life cycle of

\section{BASES}

Important studies have been devoted to gastric cancer epidemiology, histological examination of those patients gastric mucosa, functional activity measure of parietal cells, experimental carcinogenesis degrees too. Rational bases of a prevention policiy and gastric cancer detection will be found in their analysis [9].

1) Environment takes a prominent part in gastric cancer development [1]. Diet is concerned; some compounds are considered to induce (salted and smoked food, tobacco, aflatoxin, nitrosamines directly or by nitrates nitrites transformation...), others to protect (milk, green vegetables, full of vitamine $\mathrm{C}$ fruits). Exogenous and diet related factors take place in the early years of life by predisposing. Ulteriorly, all existence long, summation effect of protecting and inducing factors determines precancerous condition development and transformation into confirmed cancer. These concepts explain the very long interval between predisposition and cancer starting. When comparing Japan (country with high risk cancer) to the United States (country with low risk), one understands that a Japanese, who moved to the United States just after infancy, keeps a higher cancer risk than his american contemporary, but a lower one than the non transplanted Japanese.

2) Chronic gastritis as a precancerous lesion is the only precursor of gastric cancer. This the malignant ulcer. Gastroenterology, 1971, 60 , 835-844

11. SUGANO H., NAKAMURA K. and TAKAGI K. - An atypical epithelium of the stomach. A clinicopathological entity Gann Monograph, 1971, 11, 257-269.

12. WILLEMS G. et BLEIBERG P. - Anomalies de la synthèse d'ADN et de la vitesse de prolifération dans la gastrite atrophique chez l'homme. Arch. Franç. Mal. App. Diges. (absiract), 1976, 65,174 .

13. WOOLLAMS R., BARRATT P.J., ORWELL R.L. and PIPER D.W. - LDH isoenzyme pattern of univolved gastric mucosa of patients with gastric carcinoma and benign gastric disease. Digestion. 1976, 14, 20-28.

part is demonstrated by the epidemiological correlations between both affections and the genesis of experimental gastric cancers. Most after, intestinal metaplasia accompanies chronic gastritis. Thus, there is a strong correlation between intestinal metaplasia and gastric cancer.

3) Chronic gastritis, as an evolutive inflammatory lesion of gastric mucosa, consists of slowly renewing cells atrophy (gastric glands) and gast renewing cells dysplasia (surface and crypts epithelium). Epithelial dysplasia evolves with increasing degrees of cellular atypy and dedifferenciation with loss of mucosecreting character, reduction of cellular life and increase of mitosis frequency. Dysplasia is very often (70) \% of cases) accompanied with intestinal metaplasia with appearence of more or less differenciated enterocytes and caliciform cells. Cancer appears in the deep epithelial layer when cells renew. When dysplasia is alone, cancer is not differenciated; when there is also intestinal metaplasia, it has the intestinal differenciated type. Although intestinal metaplastic forms is very often accompanied with cancer, there is no proof it is the direct starting point. Metaplastic tissue, indeed, does not have kinetic [12] and biochemical [13] characters that are usually thought to belong to precancerous gastric mucosa. However, it can indirectly interfere in malignant transformation : thus, it has been suggested as an hypothesis that metaplastic intestinal tissus absorbed digestive cancerogenic factors that were stopped in underlying chorion. 
In fact, the successive degrees of gastric cancer can be compared to those described about colon cancer (dysplasia of adenomatous polyp) or uterine cervical cancer (dysplasia with epidermoid metaplasia). Concerning stomach, classification is : i) epithelial dysplasia with its progressive degrees, ii) microscopic cancer under $5 \mathrm{~mm}$ in diameter, iii) intramucous or larger cancer, infiltrating the mucosa, iv) invasive cancer, more and more deeply [2] coat infiltrating.

4) Can the indicators of gastric precancerous condition be searched in the analysis of gastric secretion? In fact, acid flow measure reflects fundic but non antral glands atrophy. Dosage of lactodeshydrogenase isoenzymes in gastric juice with an elevation of $\mathrm{M} / \mathrm{H}$ sub-units ratio does not have pratical bearing yet. Therefore, histological criterious collected by controlled biopsy are always primordial. The first indicator is antral or fundic glands atrophy, pinting out the associated epithelial dysplasia. Although atrophic chronic gastritis is a diffuse process, the search of precancerous condition is centred on study of limited dysplastic foci, the lightly, hightened or depressed surface of which does not exceed one or a few square centimeters. Those atypical epithelial foci $[4,6,7,11]$ are predominant on antral mucosa; they are generally multiple and can be associated with a localized gastric lesion : ulcer or cancer. Therefore, gastric cancer can have a multicentric origin. Biopsy on those foci shows either an intestinal metaplasia (elevated or depressed type) or a common dysplasia.

Swab examination permits to classify atypical epithelial focus in increasing degrees of cellular atypy, according to the cytologic characters : shape of the nucleus, nucleo-cytoplasmic ratio, general architecture of cellulars layers. One distinguishes like Nagayo [4] degree $I$ : normal mucosa, degrees $I I$ and $I I I$ : more and more marked dysplasia, degree $I V$ : very severe dysplasia, degree $V$ : cancer.

5) Macroscopic gastric cancer, at next period, spreads to a more important surface but stays limited to the mucosa and/or the submucosa. Generally, at this period, cancer looks like a larger dysplastic forms and superficially ulcerated. Ulceration can heal and recru, according to the evolutive cycle of malignant ulcer [10]. Less often, it is a deep cancer, the carter of which is dug in non tumoral tissue ; more rarely, it is a degenerated adenomatous polyp.

\section{PREVENTION}

An effective prevention of gastric cancer involves precise knowledge of carcinogenic factors and their exclusion of diet for all people, as soon as infancy. Although, there is no health policy in this field, that prevention is spontaneously realized in France as most occidental countries with industrial civilization. Gastric cancer incidence, indeed, does not stop fast decreasing in the last decades: $30,2 \%$ from 1952 to 1968 [1]. Though this « inconscious » prevention is effective, it is desirable to develop alimentary controls and analysis of cancerogenic factors in diet in order to define its rational bases.

\section{DETECTION}

Detection should be early made, so as to permit an efficient therapy : precancerous condition dysplasia at degree IV, and confirmed mucosal or submucosal cancer at microscopic or superficial degree. In Japan, mass detection applied to asymptomatic people is not interesting in our country, where gastric cancer risk is clearly lower (death rate under 20/100 000). We should limit us to detection in patients who take medical advice for digestive symptoms. Detection and watching methods will be applied to abnormal high risk people :

High risk people: patients with a localized gastric desease, together with a chronic atrophic gastritis.

- 1) Gastric ulcer (benign ulcer) involves a higher cancer risk, even disregarding possible mistake about an ulcerated cancer (malignant ulcer). That risk is bound to epithelial dysplasia foci, either on the ulcer edge or at distance. Searching examination of operative pieces, indeed, would show small cancers (microscopic cancers) at distance of a benign ulcer [5]. 
- II) Duodenal ulcer does not involve increased cancer risk on fundic mucosa but on antral mucosa. Antral gastritis lesions, when severe, have a malignant potentiel with type IV dysplasia and intestinal metaplasia; that explains paradoxical gastric cancer development in a hyper- or a normochlorhydric patient.

- III) Gastric cancer itself involves an increased cancer risk in another stomach place, because dysplastic foci are readily multicentric. Detection of those foci before surgery will be able to make a better choice of resection width and to diminish recurrence risk on the staying gastric mucosa.

- IV) Adenomatous polyp is capable of malignant degeneration, but the risk is not avoided by polypectomy because cancer can spead at distance on dysplastic foci. Although non adenomatous hyperplastic polyps do not degenerate, they involve the same cancer risk at distance of the lesion, because they occur on an atrophic gastritis mucosa.

- V) At last, every patient with a large gastric resection has a higher cancer risk because intestinal reflux favours development of epithelial dysplastic lesions in the staying sto. mach.

In patients complaining of usual dyspeptic troubles with lccalized gastric desease, gastric epithelial dysplastic lesions in the staying stoatrophy confirmed by histology and hypochlorhydria involves a higher cancer risk as to 50 years old) permits to anticipate a cumulative effect in terms of time. Association of a complete achlorhydria and a pernicious anemia has a considerable risk, the pratical bearing of which is often minimized by patient's old age at the time of the detection.

Watching method: X-ray, if made in double contrast, can detect superficial lesions of gastric mucosa ; it cannot be compared to endoscopy, because it cannot permit histological exami- nation of dysplastic foci. Nowadays, high risk patients watching rests on endoscopy only. This one should imperatively meet the requirements of a watching examination repeated every twelve or twenty-four months. One should be effective without discouraging the patient. Now there is a tendancy towards those methods: a) examination with small calibre equipment, but it is necessary to impose biopsies quality ; b) to resort to coloring techniques (as methylen by increasing relief contrasts and by using colouration differences of normal mucosa (unblue) in order to mark atypical epithelial foci coloured), intestinal mucosal (a little coloured); c) fine analysis of dysplastic epithelial architecture [3], varying the focus ; d) classification of dysplastic lesions in increasing cellular atypy, degrees; e) strictness of iconography in order to keep an objective reference of mucosa aspect at a certain time.

\section{CONCLUSION}

A policy of an early gastric cancer detection is regularly followed by a progress in ratio of cancers, which are detected at mucosal or sub-mucosal period and are unable by surgery. Those superficial cancers are detected by systematic biopsy, when gastric ulcer and large plane lesion (type II, a, b, c cancer). Gastric resection indication is not questionable, except when patient age or visceral defects association suggests a disproportionate operative risk.

Pratical application of an early detection policy are more difficult to define when precancerous conditions or dysplastic foci at period IV. Should one have to propose right away a radical solution, i-e gastric resection? That could enlarge excessively operative indications number should one tighten watching rythm? Shou!d one give place to endoscopic microsurgery with laser? We should wait some years for the answer. 